\title{
An Overview of the Amazonian Craton Evolution: Insights for Paleocontinental Reconstruction
}

\author{
Mauro Cesar Geraldes, Armando Dias Tavares, Anderson Costa Dos Santos \\ Rio de Janeiro State University, Maracanã, Rio de Janeiro, Brazil \\ Email: geraldes@ueri.br, tavares.armandodias@gmail.com, costasantos@gmail.com
}

Received 20 July 2015; accepted 25 September 2015; published 28 September 2015

Copyright (C) 2015 by authors and Scientific Research Publishing Inc.

This work is licensed under the Creative Commons Attribution International License (CC BY). http://creativecommons.org/licenses/by/4.0/

(c) (i) Open Access

\begin{abstract}
The Amazonian craton major accretionary and collisional processes may be correlated to supercontinent assemblies developed at several times in the Earth history. Based on geologic, structural and paleomagnetic evidence paleocontinent reconstructions have been proposed for Archean to younger times. The oldest continent (Ur) was formed probably by five Achaean cratonic areas (Kaapvaal, Western Dhawar, Bhandara, Singhhum and Pilbara cratons). Geologic evidences suggest the participation of the Archaean rocks of the Carajás region in the Ur landmass. Supercontinental 2.45 Ga Kenorland amalgamation is indicated by paleomagnetic data including Laurentia, Baltica, Australia, and Kalahari and Kaapvaal cratons. There is no evidence indicating that Amazonian craton was part of the Kenorland supercontinent. From $1.83 \mathrm{Ga}$ to $1.25 \mathrm{Ga}$ Columbia and Hudsonland supercontinents including Amazonian craton were proposed based on NE portion of the Amazonian craton (Maroni/Itacaiunas province) connection with West Africa and Kalahari cratons. Rodinia supercontinent reconstructions show Amazonia joined to Laurentia-Baltica as result of 1.1 Ga to 1.0 Ga fusion based on the Sunsas-Aguapei belts and Greenville and Sveconorwegian belts, respectivelly. The large Late Mesoproterozoic landmass included also Siberia, East Antartica, West Nile, Kalahari, Congo/São Francisco and Greenland. The 750 - 520 Ma Gondwana assembly includes most of the continental fragments rifted apart during the break-up of Rodinia followed by diachronic collisions (Araguaia, Paraguay and Tucavaca belts). The supercontinent Pangea is comprised of Gondwana and Laurentia formed at about 300 - 180 Ma ago. The Amazonian craton margins probably were not envolved in the collisional processes during Pangea because it was embebed in Neoproterozoic materials. As consequence, Amazonian craton borders have no record of the orogenic processes responsible for the Pangea amalgamation.
\end{abstract}

\section{Keywords}

Amazonian Craton, Tectonic Evolution, Paleocontinents 


\section{Introduction}

The Amazonian craton (Figure 1) is one of the more complete examples of continental crust growth throughout Archaean to Mesoproterozoic. The geologic evolution within this period of time included accretion of juvenile (subduction-related) material and cratonic fragments [1]-[5]. The ages, structures, and compositions of rock units and orogenic events within Amazonia are still imperfectly known, in spite of significant recent advances [6] [7]-[15]. Amazonia is a key piece of the puzzle for many supercontinent reconstructions [16]-[25]. The tentative reconstruction of these paleocontinents takes into account paleomagnetic data, orogenic belts match, geologic provinces match, fossil assemblages and glaciogenic sequences. This work deals with the continental growth of the Amazonian craton and the relationship of these accretionary and colisional processes and supercontinent amalgamations throughout geologic time.

\section{Paleomagnetic Concepts}

The reconstruction of paleocontinents has been proposed for Archean to younger times. Most of the proposed configurations are based on analyses of geologic and structural evidences but include paleomagnetic database with paleogeographic position and age for each pole. Paleomagnetic pole positions have long been calculated with the assumption that the ancient geomagnetic field was purely that of a geocentric dipole [26]. In addition, the true polar wander (TPW) is described as different poles of the same landmass in different times based on a Earth's geographic reference (Figure 2). The sequence of poles displayed in a map (or on a globe surface) defines the trajectory of the landmass during that period of time.

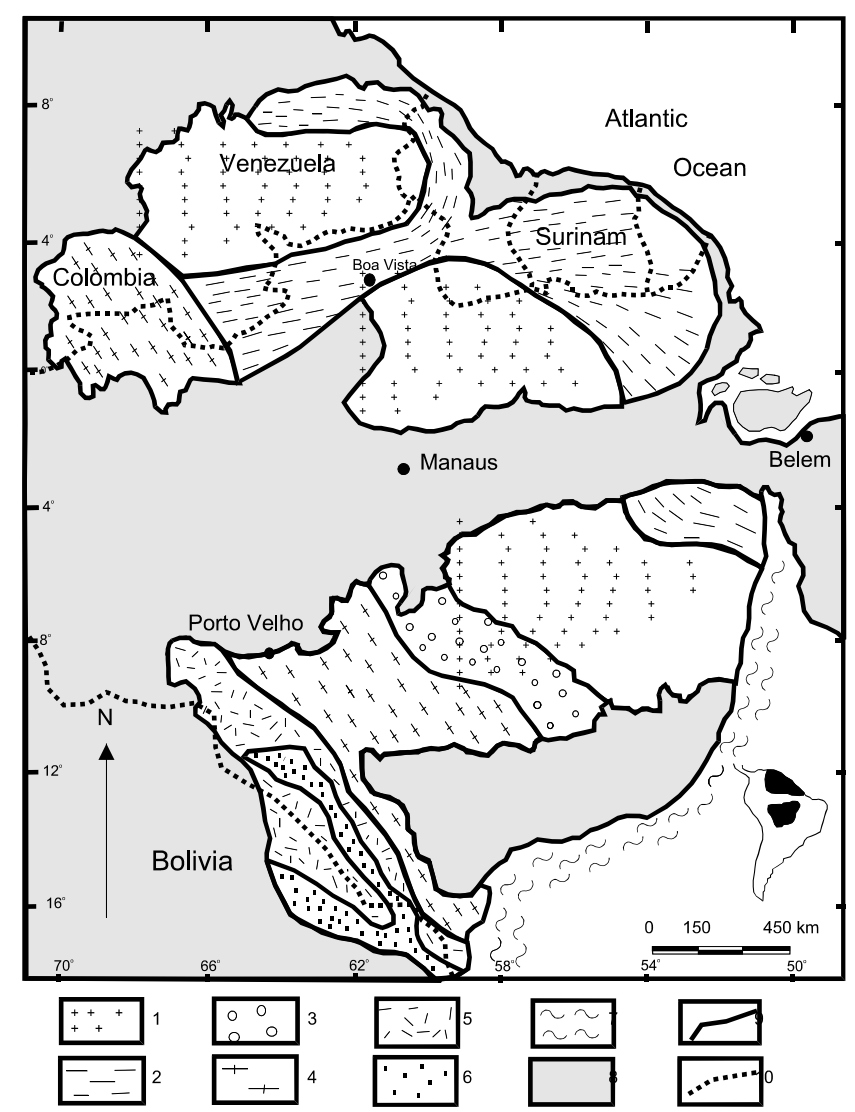

Figure 1. The Amazonian craton tectonic provinces according to Teixeira et al. [26] (1989). 1) Central Amazonia; 2) Maroni-Itacaiúnas; 3) Ventuari-Tapajós; 4) Rio Negro-Juruena; 5) Rondoniana-San Ignácio; 6) Sunsas-Aguapeí; 7) Mobile belts; 8) Sedimentary basins; 9) Province borders; 10) Country borders. Modified from [25]. 


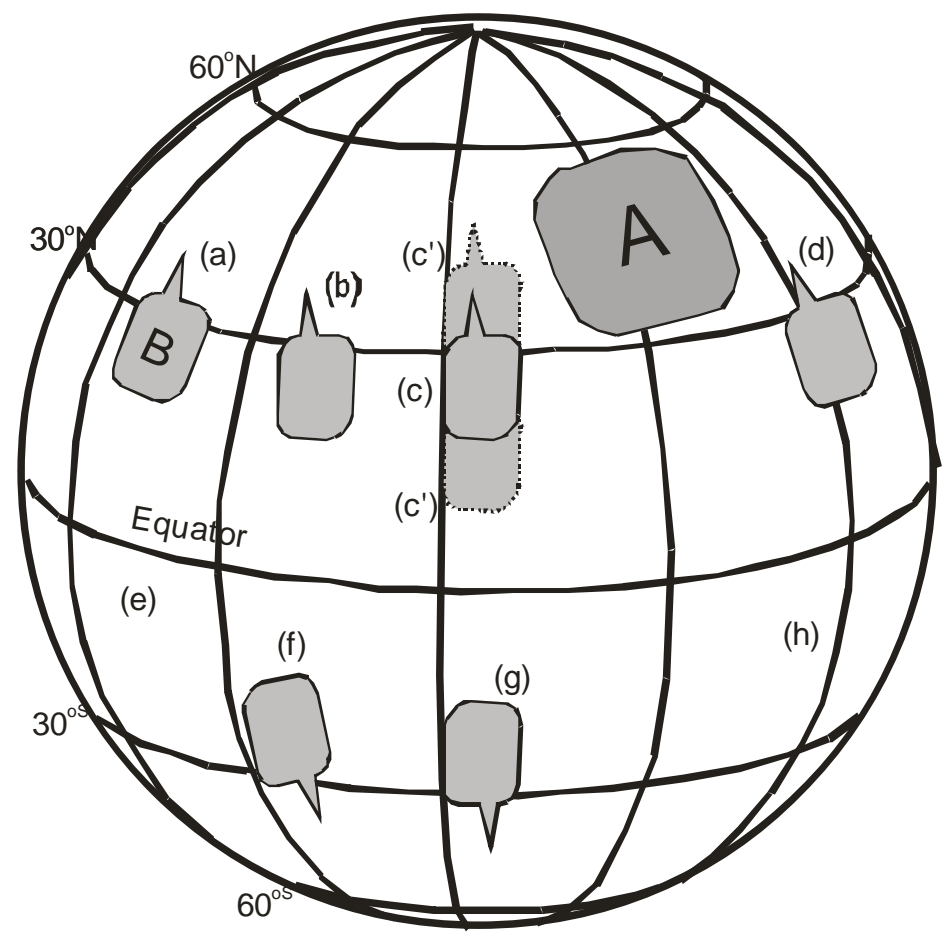

Figure 2. Paleomagnetic poles plotted on an Earth's geographic reference.

At least since the Mesoproterozoic Earth's lithosphere has contained just enough continental material to occupy about a hemisphere when all elements are aggregated [28] [29]. The elements of our planet are in relative motion, requiring approximations of processes operating at timescales encompassing several orders of magnitude. TPW is consistent with continental mobilism corroborated with geological observations. In this way, TPW is measurable today at a rate of about $10 \mathrm{~cm} /$ year. Estimates long-term Mesozoic-Cenozoic TPW rates are typically about $1-5 \mathrm{~cm} /$ year [29].

[30] had illustrated several way how the TPW may be interpreted, as showed in Figure 3. The plotted poles (TPW) of a specific landmass (Figure 3(a)) when compared with other landmass poles may indicate a collision between both or rifting process (Figure 3(b)) and amalgamation (Figure 3(c)). The Wilson cycle may be obtained when two landmasses are together at the beginning, followed by a separation and the final collision. The amalgamation of several landmasses may be indicated when a group of landmasses are at the same "place" at the same time.

\section{The Archean Continent (Ur)}

The continental growth in Amazonian craton started during the Late-Archaean when microntinental cell amalgamation resulted in a continuous sialic crust at about $2.76 \mathrm{Ga}$. The formation of these fragments started about $3.05 \mathrm{Ga}$ as exampled by the Pium mafic-ultramafic complex. The highly speculative continent of Ur [31] [32] is evidenced only in five Achaean cratonic areas (Kaapvaal, Western Dhawar, Bhandara, Singhbhum and Pilbara cratons) where 3.0 - $2.8 \mathrm{Ga}$ shallow-water supracrustals assemblages are observed. Such as sedimentary units are coeval to sediments of Agua Clara formation intercalated with volcanic rocks (2.97 - $2.90 \mathrm{Ga}$ ) and cut by 2.76 Ga mafic-ultramafic layered complex in the Amazonian craton [33]. The sedimentary rocks are comprised of platformal cover suites (pellite, BIF, chert, shale and greywacke) and may suggest the participation of the Achaean rocks of the Carajás region in the Ur landmass (Figure 4).

\section{Paleoproterozoic Reconstructions (Kenorland, Arctica and Antartica)}

The Paleoproterozoic geologic history of the Amazonian craton included huge volume of juvenile magmatism. The lateral accretionary events of the Maroni-Itacaiunas province in the NE sector of the Amazonian craton is 

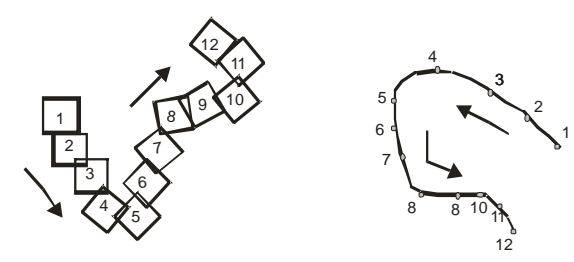

\section{A. Single Continent}
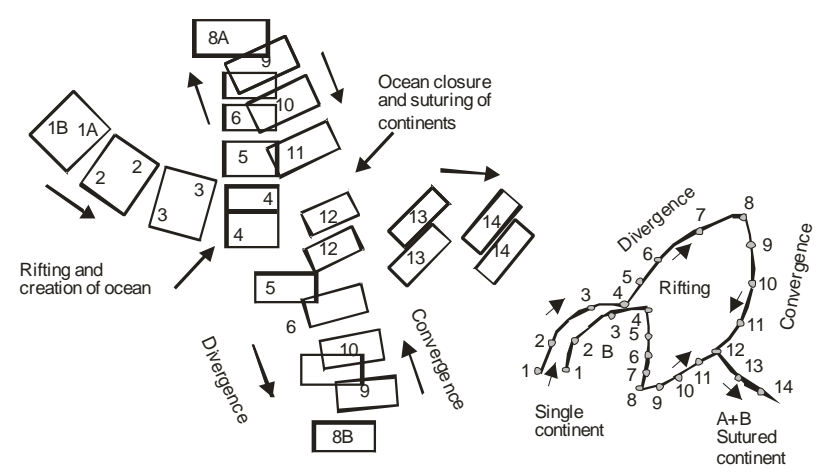<smiles>[CH]C=O</smiles>

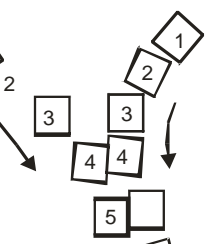
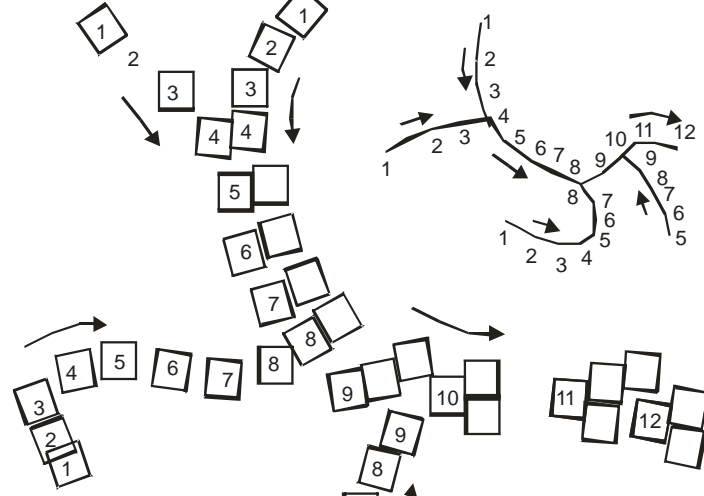

\section{B. Wilson Cycle}

Figure 3. Possible reconstructions of landmasses relationship based on True Polar Wander (TPW). Modified from [29].

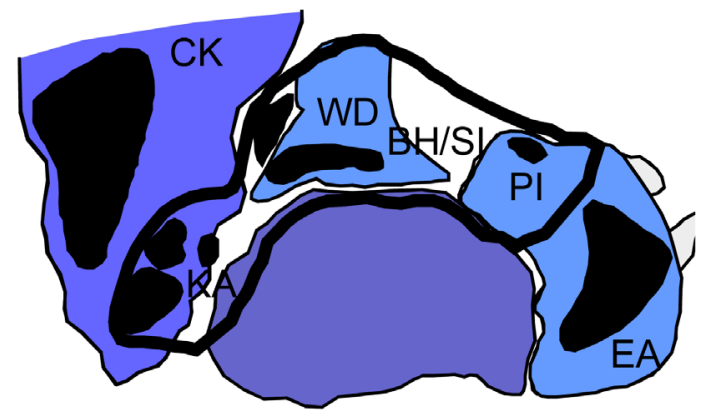

\section{Cratons}

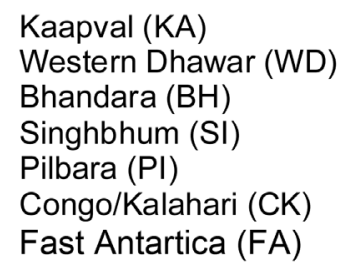

Figure 4. Ur continent reconstruction [32].

demonstrated upon geochronological studies carried out by [7] [11] [14] in French Guyana and Amapa (Brazil). These investigations yielded ages about 2.26 - 2.20 Ga interpreted as the time of juvenile rocks (gabbro and tonalite) formations in magmatic arc setting followed by collisional magmatism (at about $2.19-2.13 \mathrm{Ga}$ ) represented by granitoids. Supercontinental collage during Paleoproterozoic times is indicated by paleomagnetic data according to [25]. In this way, the Kenorland (Figure 5) amalgamation includes Laurentia (Superior and Wyoming cratons), Baltica (Karelia craton), Australia (Yilgarn craton), and Kalahari and Kaapvaal cratons at 
about $2.45 \mathrm{Ga}$. A second continental mass is proposed at that period of time by [34]. The Zimvaalbara landmass was composed by Zimbabwe, Kaapvaal and Pilbara cratons based on paleomagnetic informations. Between 2.40 2.20 Ga Superior, Karelia and Kalahari cratons experienced successive glaciations, recorded by glaciogenic units and paleoweathering layers (strongly indicating their previous collage) and the lack of such sedimentary rocks suggest that Amazonian craton (where only platformal basin sedimentation was recorded at that time according to [35] was not part of the Kenorland supercontinent (Figure 6), which had its break up during rifting processes ca. 2.20 - $2.21 \mathrm{Ga}$.

The continent Arctica (Figure 7) was proposed by [31] from 2.5 Ga to 1.8 Ga. This continent includes Laurentia (Slaves, Wyoming, Superior cratons and Rae and Hearne provinces), Siberia (Aldan and Anabar craton) and Greenland and probably the Amazonian craton did not participate of this landmass. By other hand, [31] also proposed the continent Atlantica, formed at about $2.0 \mathrm{Ga}$ and comprised of Amazonian, São Francisco, Rio de La Plata, West Africa, West Nile and Congo/Kalahari cratons. The interval ages of subduction and collision

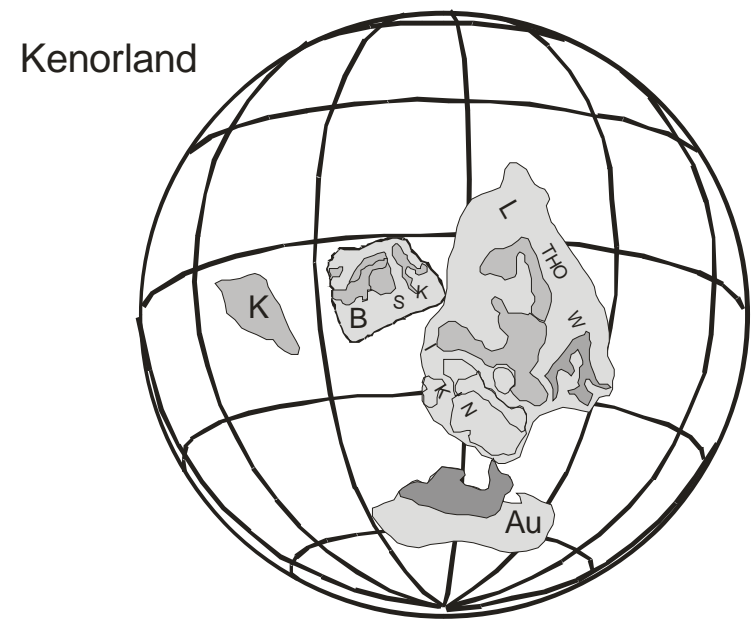

Figure 5. Kenorland paleocontinent reconstruction (Modified from [25]).

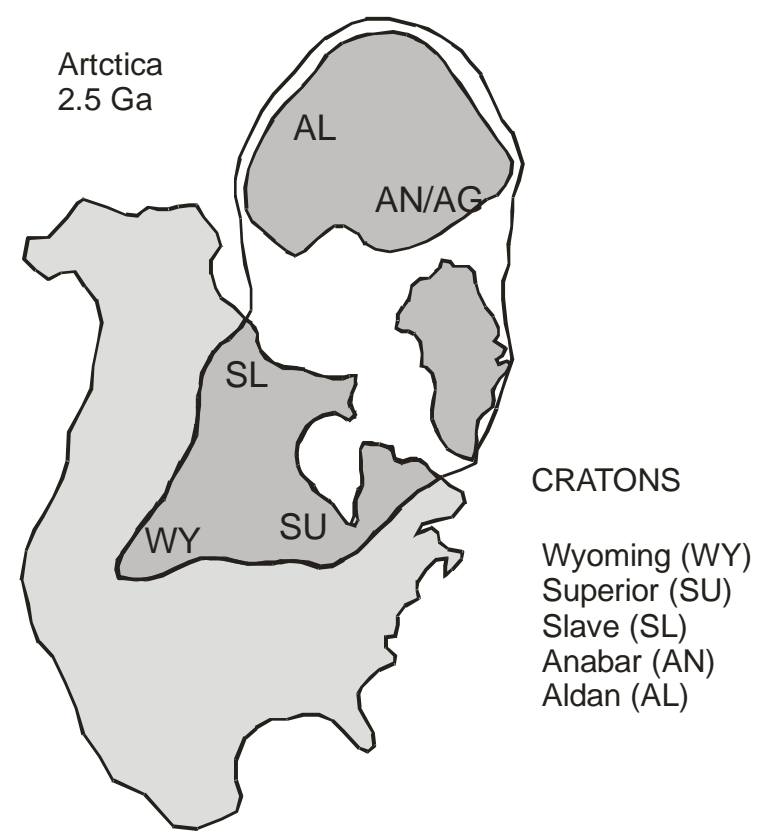

Figure 6. Arctica paleocontinent reconstruction (Modified from [32]). 


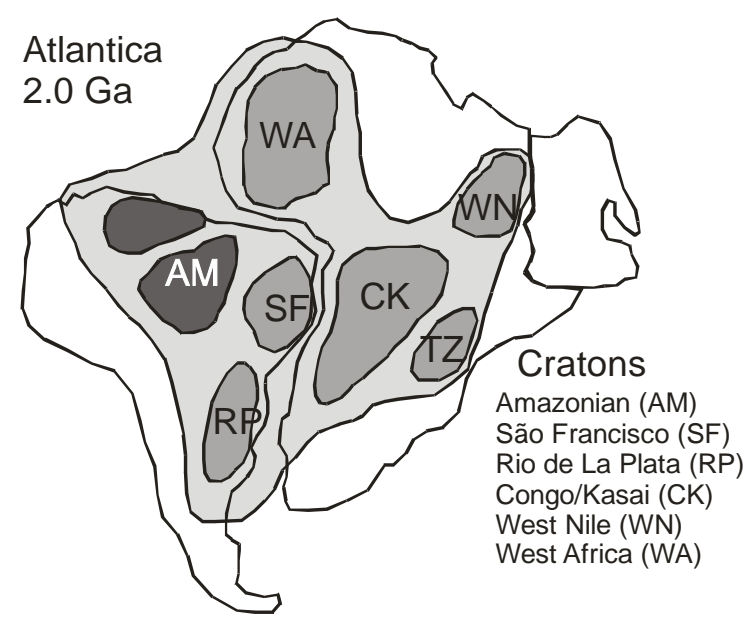

Figure 7. Antartica paleocontinent reconstruction (Modified from [32]).

(2.26 - $2.13 \mathrm{Ga}$ ) in French Guyana and Amapa (Brazil) suggest the collage of Amazonian and West Africa cratons as pointed out by [33] [35] suggested the inclusion of the Amazonian-West Africa cratons in the Atlantica supercontinent of [31] based also on the intracratonic environment of the Uatumã volcanic (piroclastic and lava flows) rocks formed from 1.97 to $1.85 \mathrm{Ga}$ [36].

The Tapajós province developed in the SW portion of the Achaean province from 2.05 Ga to 1.88 Ga [3] [4] [8] [9]. The juvenile rocks of this province are comprised of calcalkaline magmatism dated at $2.05-1.96 \mathrm{Ga}$ (Cuiu-Cuiu magmatic arc) followed by Alto K'Parauari granitoids $(1.88 \mathrm{Ga}$ ) defining at least two accretionary events. At the same time (2.00 - $1.96 \mathrm{Ga}$ ) in Roraima (northern portion of the Amazonian craton) calcalkaline juvenile rocks were found by Reis et al. [5]. These $2.05-1.88 \mathrm{Ga}$ orogenic belts in the SW margin of Amazonia may indicate a continuous (lateral) accretionary process with juvenile characteristics without collisional process recorded within this period of time.

\section{Paleo-Mesoproterozoic Reconstructions (Columbia and Hudsonland)}

The Mesoproterozoic geologic evolution of SW of the Amazonian craton is comprised of juvenile accretions and crustal rework. This region has been divided into three major domains ([2] [36]: the Rio Negro-Juruena 1.79 1.52 Ga), the Rondonian-San Ignácio (1.51 - 1.34 Ga), and the youngest Sunsás-Aguapeí (1.24 - 1.00 Ga). Each province has been divided into orogenic belts. In this way, the Rio Negro/Juruena Province is represented by the 1.79 - 1.74 Ga Alto Jauru and the 1.58 - 1.52 Ga Cachoeirinha magmatic arcs ([6] [37], respectively). The Rondonian/San Ignácio Province is marked by important events involving magmatic arc settings and continental collision processes between $1.51 \mathrm{Ga}$ and $1.34 \mathrm{Ga}$. These comprise the 1.51 - $1.48 \mathrm{Ga}$ Rio Alegre, the 1.45 - 1.42 Ga Santa Helena and the 1.42 - 1.32 Ga San Ignácio arcs [2] [38].

From 1.83 Ga to 1.25 Ga two supercontinents including Amazonian craton were proposed. The first named Columbia (Figure 8; [31] [39]) takes in account paleomagnetic and tectonic data and substitute the earlier proposition of the Nena continent (Figure 9 and Figure 10) suggested by [30]. The authors suggest the NW portion of the Amazonian craton (Maroni/Itacaiunas province) in close connection with West Africa and Kalahari cratons at about $1.80 \mathrm{Ga}$. Corroborating this hyphothesis large area of Amazonia were covered by cratonic and subordinate shallow marine sedimentary rocks. The Roraima Group is an example of these sequence formed at this time by marine sediments passing upward to continental and intertidal deposits.

The second paleocontinental proposition is known as Hudsonland characterized by [25]. These authors suggested this 1.83 - 1.25 Ga landmass comprised of Laurentia, Baltica and Amazonia, even the complete consolidation of Laurentia fragments was not finished at that time [27]. In this proposition the Ventuari/Tapajós province of the Amazonian craton is linked to Laurentia/Baltica but this large continent probably included other continents such as Australia, Siberia, Ukraine and North China, although paleomagnetic data are still lacking [25] (Figure 11). 


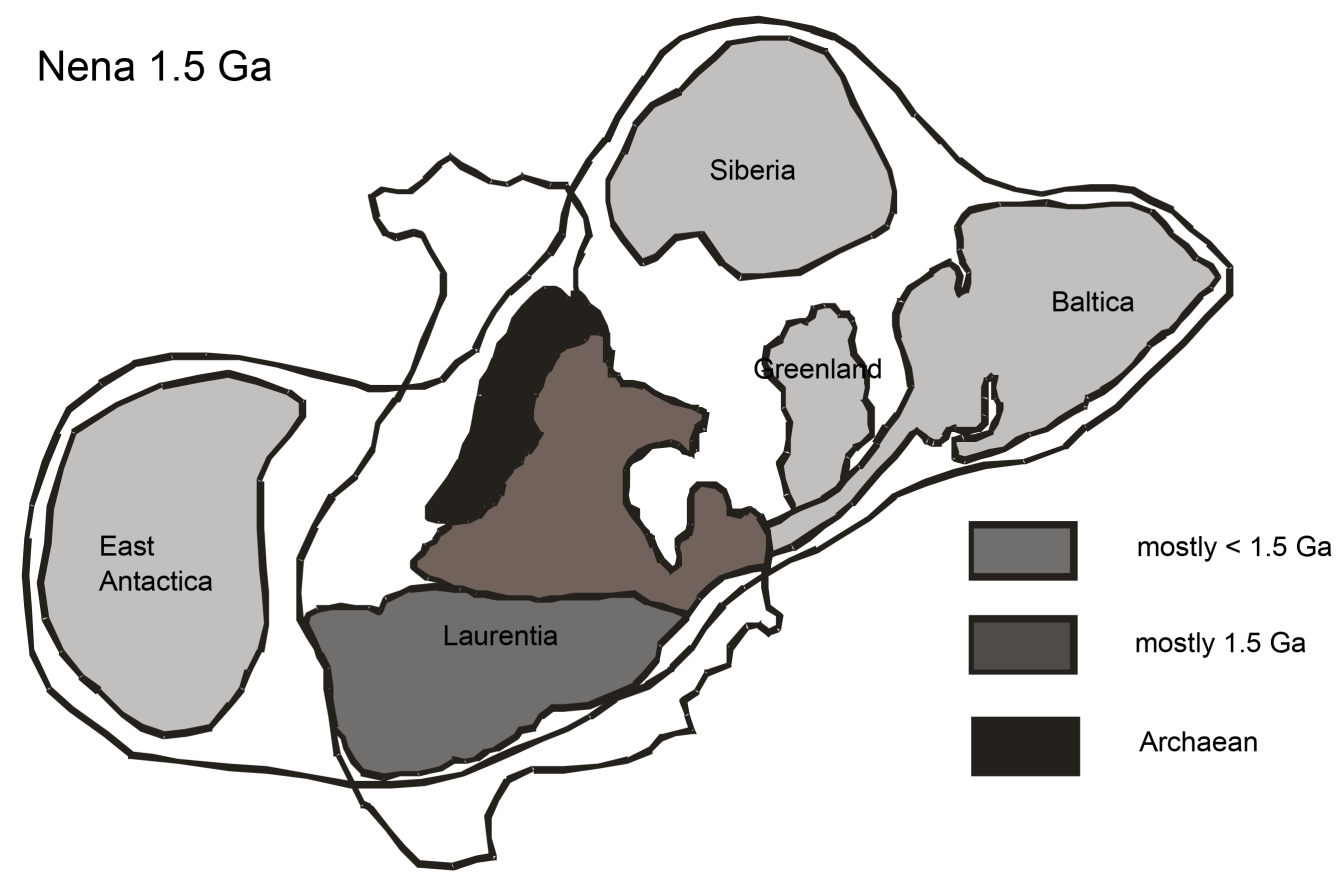

Figure 8. Nena paleocontinent reconstruction (Modified from [30]).

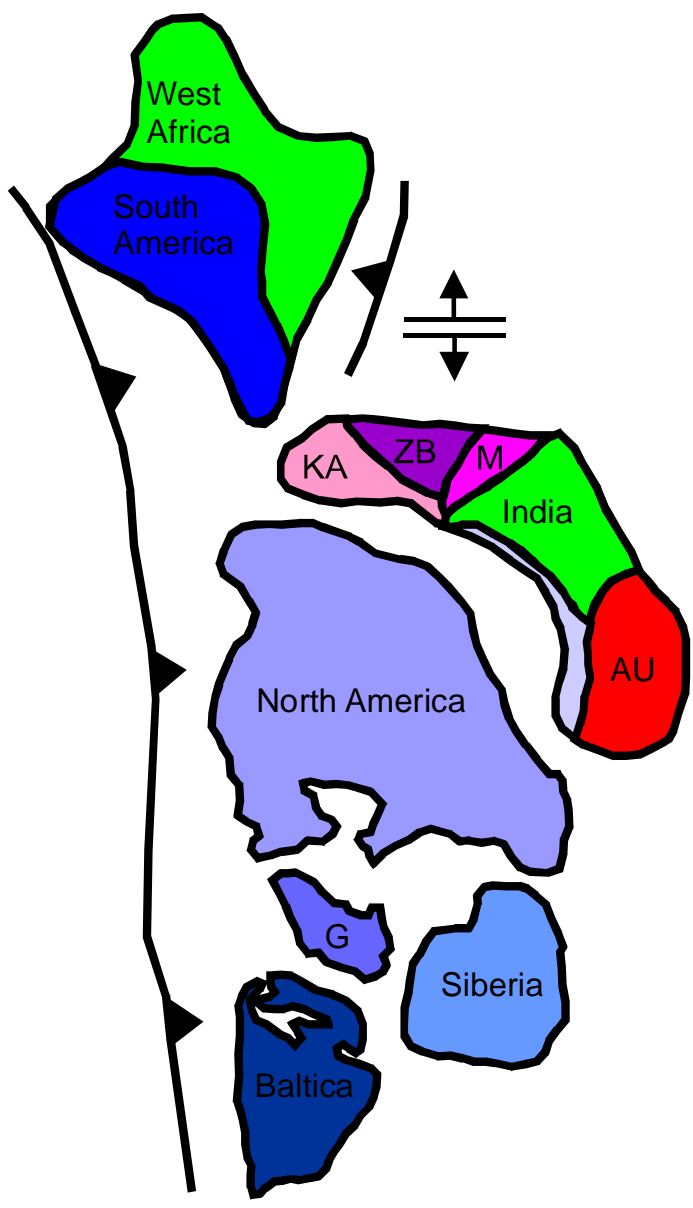

Figure 9. Columbia paleocontinent reconstruction (Modified from [31] [32]). 


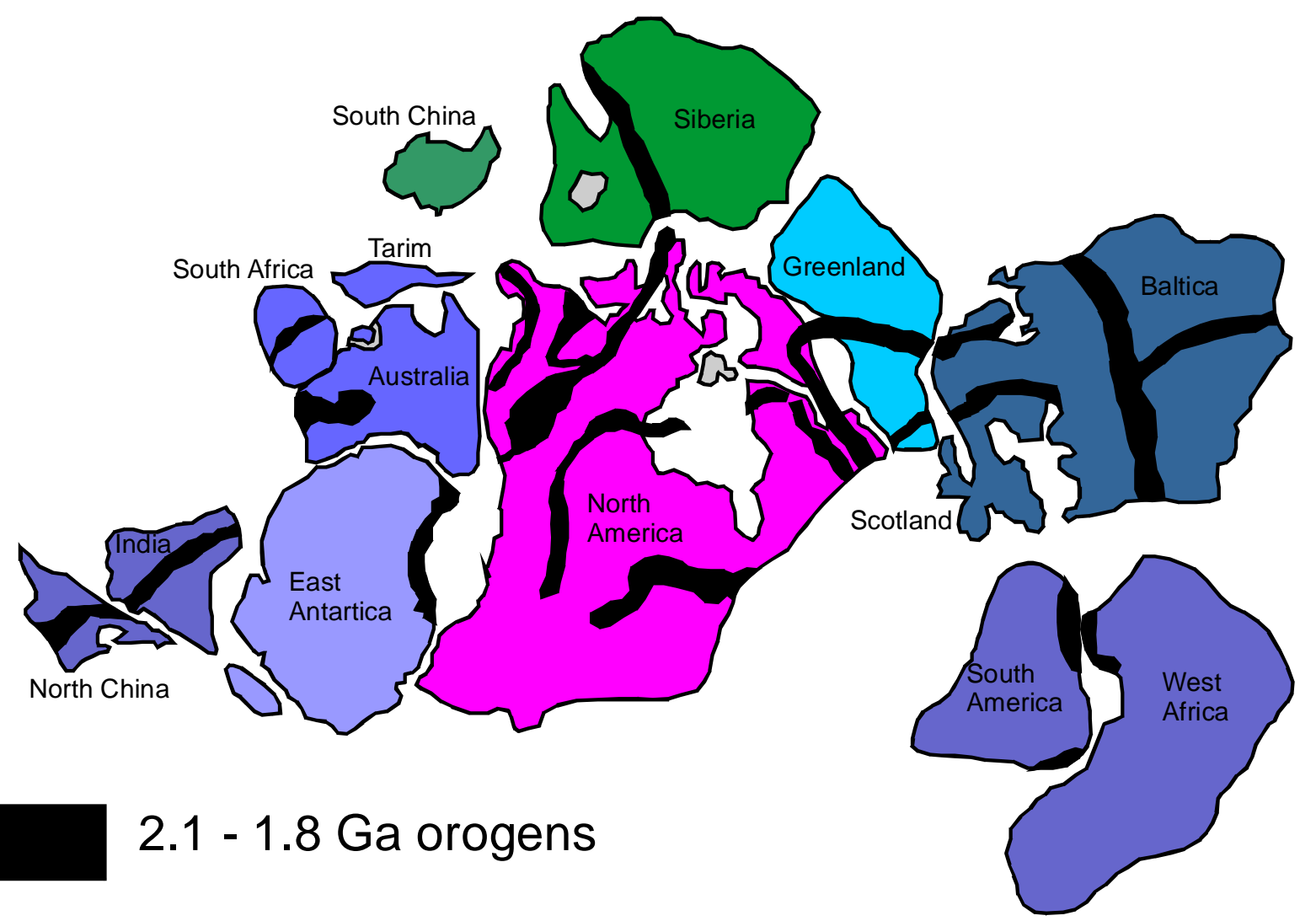

Figure 10. Columbia paleocontinent reconstruction (Modified from [39]).

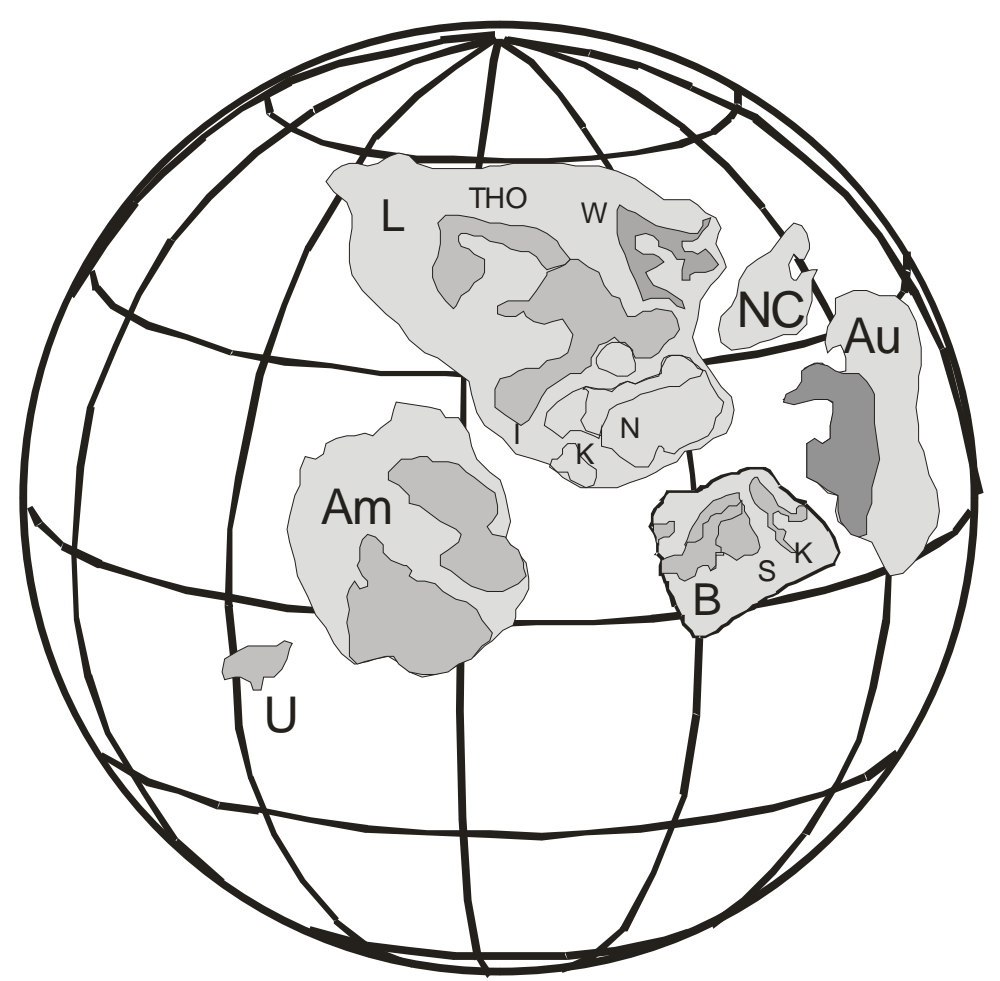

Figure 11. Hudsonland paleocontinent reconstruction (Modified from [25]). 
The Amazonia connection with Laurentia/Baltica during the Hudsonland existence may help with 1.57 - 1.0 Ga rapakivi granites origin approach. In this way, the coeval AMCG suites observed in Baltica and Amazonia strongly suggest a continuous continental margin where orogenic processes accretionated juvenile material and the coeval anorgenic intracratonic magmatism may be explained as representing distal expressions [40] [41] of the long lasting accretional margin. Other genetic hypothesis proposed to the $1.88 \mathrm{Ga}$ anorogenic magmatism [42] [43] and proterozoic anorogenic magmatism in Laurentia [44] take into account the existence of mantle plume or downwelling flow in the mantle, respectivelly. The Hudsonland last until 1.25 Ga when rifting process due mantle plume activity resulted in break up landmass followed by fragments drifting.

Several sedimentary sequences corroborate with Hudsonland hypothesis. The Mesoproterozoic deposits in the central and western part of the Amazonian craton include Prosperança, Acarí and Prainha units comprised of clastic sediments such as coarse graines and micaceous conglomerate. Alkaline basalts are intercalated with arkosic sandstone. Gabbro and diabase intrusions have poorly ages defined at 1.4 - 1.2 Ga. In the eastern part of Amazonia the Cubencranquém Group is comprised of more than $300 \mathrm{~m}$ of reddish arkoses sandstones. In the SW part of Amazonian craton the (1.3 - 1.1 Ga) Aguapei Group is comprised of conglomerates, sandstones and siltstones [45].

\section{Late Mesoproterozoic Reconstructions of Rodinia (Auswus, Swets and Ausmex)}

The youngest Sunsás/Aguapeí Province is comprised of sequences deposited during basin tectonic (1.1 Ga Nova Brasilândia and 1.0 Ga Aguapeí [46] [47] (respectively) and magmatic products (1.0 Sunsás; [48] [49]).

The lack of orogenic events between 1300 - 1250 Ma in the SW Amazonian Craton indicates the initial period of sedimentation referable to the Sunsás, Aguapeí, and Nova Brasilandia basin. The Sunsás orogen has been considered as resulting of the inversion of a passive continental margin, encompassing deep marine turbiditic sediments that have experimented subduction. The deformation and metamorphism in Aguapeí Group (ca. 970 $\mathrm{Ma}$ ) are probably inboard manifestations (fold and thrust belt) of the more intense continent-continent collision occurring to the west in Bolivia (ca. 1.000 Ma Sunsás Orogen). Important anorogenic magmatism is reported widespread SW Amazonian Craton during this period of time. Between 1.1 and $1.08 \mathrm{Ga}$ important units recorded in the Nova Brasilândia Terrane and linked to the rifting stage include mantle-derived tholeiitic sill, stocks, gabbro and diabase dykes, emplaced at $1150 \mathrm{Ma}$ [46].

Hoffman [16], Dalziel [17] [18] and Meert and Torsvik [50] show Amazonian craton joined to Laurentia-Baltica in Rodinia (Figure 12) as a result of 1.1 to 1.0 Ga fusion based on the greenvillian-age SunsasAguapei belts. Others authors that suggested plate reconstruction and interpreted the Amazonian craton as the

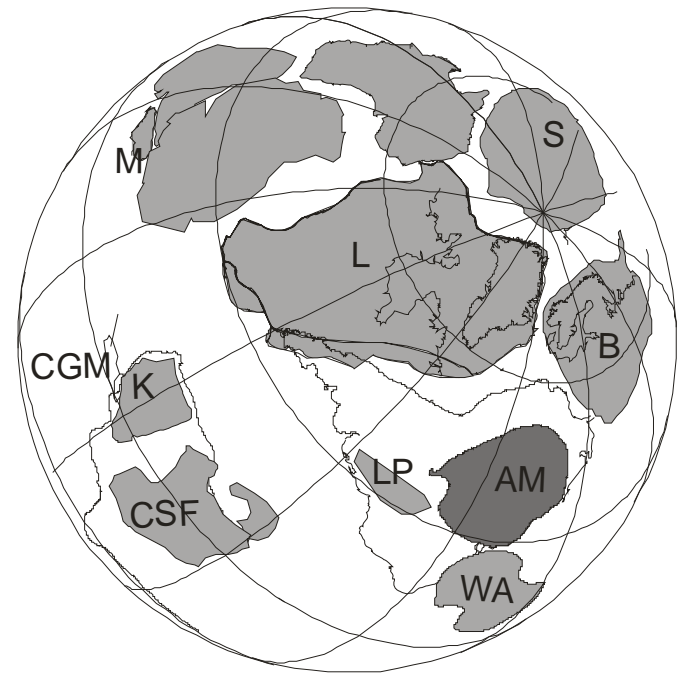

Rodinia (1000 Ma)

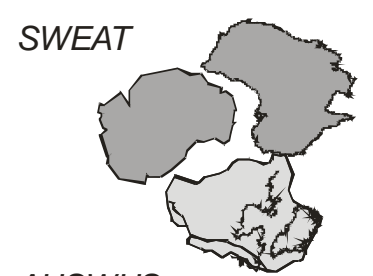

AUSWUS

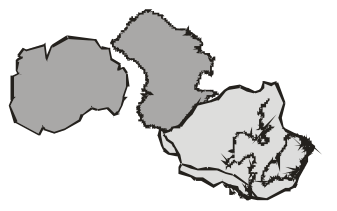

AUSMEX

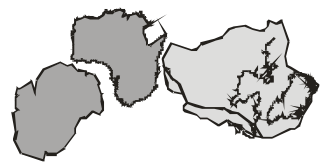

Figure 12. Reconstructions of Rodinia (SWEAT, AUSWUS and AUSMEX hypothesis) ([63]). 
colliding continent are [19] [20] [51] [52] including Siberia, East Antartica, West Nile, Kalahari, Congo/São Francisco and Greenland. [21] suggested that Amazonia was also joined to Laurentia-Baltica at 1.6 Ga and separated from it during Mesoproterozoic rifting [53] that began a Wilson cycle which ended with formation of Rodinia. [22] [23] presented paleomagnetic data that support the juxtaposition of Amazonia with Laurentia-Baltica ca. 1000 Ma what is corroborated by the geologic data described in the Sunsas-Aguapei belts [47] [48] [54] and Greenville [55] and Sveconorwegian [56] in addition to the palomagnetic data comparison. In addition, [24] presented important paleomagnetic data indicating previous Amazonia and Laurentia connection at 1.20 Ga.

During this period of time (1.15 - 0.8 Ma) the supercontinent Rodinia reconstruction takes in account the presence of the Amazonia craton in different ways cited as SWEAT initially suggested by [57] and advanced by [58] (1991), [16] (1991) and [19]; Other two Rodinia reconstruction hypothesis proposed are refered as AUSWUS [59] and AUSMEX [25] configurations. The first one comprises a proposition where Australia is connected to the (actual) NW part of Laurentia. The second proposition Australia is connected to the (actual) western part of Laurentia. And the last hyphothesis Australia was connected to the (actual) SW part of Laurentia where Mexico territory is located.

Post-Rodinia sedimentation is well recorded in SW Amazonian craton and includes Palmeiral, São Lourenço (oligomitic conglomerate), Pacaas Novos (feldspathic sandstones and siltstone and argilite intercations), Uopianes (arkosic sanstones intercalated with ash-tuff volcanoclastic rochs) deposits [60]. Post-Rodinia anorogenic magmatism Santa Clara (1.052 Ma), Costa Marques (1.018 Ma) an Young granites of Rondonia (995 Ma) are characterized as bimodal A-type rapakivi granites.

The breakup of Rodinia started at about $0.9-0.8 \mathrm{Ga}$ as result of plume action beneath the large long lasting landmass [16] [61]. The separation of the fragments was responsible for the development of widespread Neoproterozpoic sedimentary and volcano sedimentary domains, many of which have been transformed into mobile belts [62].

\section{Neoproterozoic Reconstructions (Gondwanaland)}

The Gondwana includes all the continental fragments on Earth, with exception of the Laurasia land. This collage was the result of the assembly of cratonic fragments, with special regard to Precambrian of the South America Platform, related to the huge continental lithosphere plates [62] [64] that were rifted apart during the break-up of Rodinia at the beginning of the Neoproterozoic [18] [63]. Successive collision and plate indentation processes during the global Brasiliano-Pan African orogenic cycle record the further amalgamation of these shields to form the Gondwana Supercontinent (Figure 13) [65]-[67].

The oldest pre-collisional activity in South America platform is recorded in the Brasilia belt, with the development of the Mara Rosa magmatic arc at ca. 930 - 820 Ma [68] and the closure of the Goianides ocean. Continental collision started at ca. 760 Ma with the dockage of Archean and Mesoproterozoic terranes (Figure 13(a)). The Brasilia belt (including older terranes) was the result of the ca. 630 Ma collision of the São Francisco craton and the Rio de la Plata craton (and its probable extension represented by the Rio Apa Block, a cratonic fragment underlying the sedimentary rocks of the Paraná basin named Paranapanema block). In southern Brazil occurred the São Gabriel magmatic arc at ca. 750 - 700 Ma [69], indicating an ocean closure (probably an extension of the Goianides ocean) and starting the assembly of Rio de la Plata and Luis Alves cratonic fragments (Figure 13(b)). The collision betweem Amazonian craton and West Africa craton is recorded by the Gurupi belt, which ages are about 580 - 540 Ma (Figure 13(c)).

Following the crustal history cited above, the collision of the southern region of the Amazonian craton occurred not only with the Paranapanema cratonic fragment. At that moment (541 - $531 \mathrm{Ma}$ ) important terranes and microplates had already assembled. Probably the São Francisco craton was joined to Rio de La Plata cratonic fragments (Figure 13(d)). In this way the Amazonian craton collided at 541 - 531 Ma with this continuous continental mass (São Francisco-Rio de la Plata-Luis Alves). In addition, the Rio Apa block collided to the Rio de La Plata craton and originated the southernmost branch of the Paraguay belt [70] (Figure 13(d)); and the collision between the Rio Apa block and Amazonian craton originated the western branch of the Paraguay belt denominated as Tucavaca [48] (Figure 13(d)). Practically simultaneously to these collisions, there occurred the collision of the last accretion of Ribeira belt in SE Brazil (Buzios orogeny), corresponding to the collision of the Congo craton and the São Francisco craton (Figure 13(d)). And probably at the end of these two last orogenies 


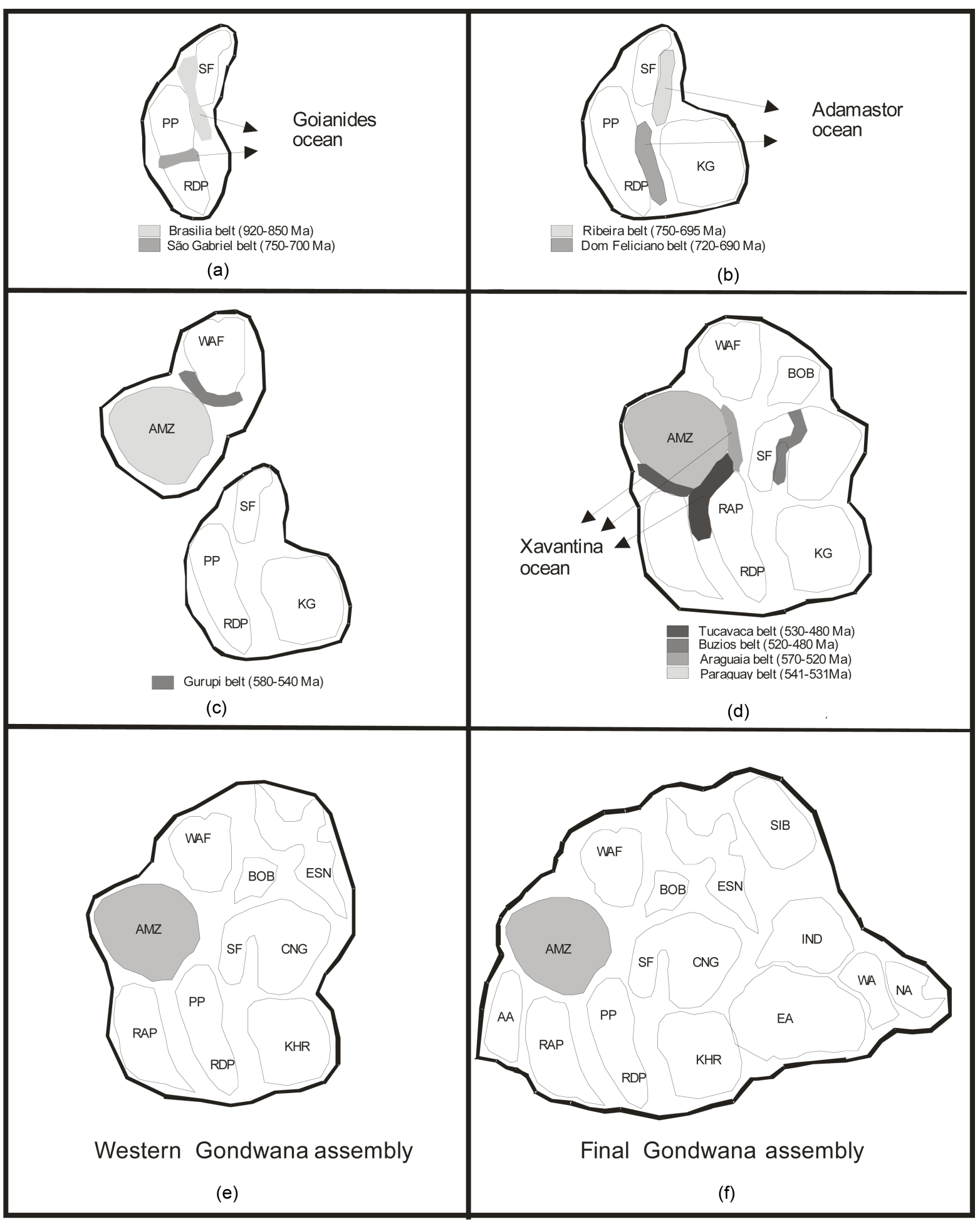

Figure 13. Reconstruction of Gondwanaland.

(Figure 13(e) and Figure 13(f)), the Gondwana supercontinent was formed.

The more extensive occurrences of sedimentary rocks related to the Gondwana supercontinent amalgamation lie on Proterozoic syneclises along depositional sites that later became depocenters throughout the Paleozoic. The filling of these syneclises show cratonic sequences as recorded by the Silurian-Devonian and Eo-Carboni- 
fefous units comprised of mature sediments with chrono-paralel beds developed under glacial conditions. The late-Carbonifeorous to Triassic sequence records several glacial episodes, marine regressions and ultimately deposition of continental sediments containing red beds [32].

\section{Paleozoic Reconstruction (Pangea)}

The supercontinent Pangea (Figure 14) was formed by the collision of the Gondwana and Laurentia about 300 Ma ago. This assembly occurred mostly in the middle to late Paleozoic, culminating the collision of nortwest Africa with eastern North America [65]. The largest area of accretion was in Asia, where the North and South China and Kasakstan cratons were embebed in broad suites of arcs and oceanic materials [32]. Microplates and juvenile material formations also are observed in Europe at this time. In this way, South America margins were not involved in the collisional processes during Pangea collage, and consequently the Amazonia craton was part of an interior land. As consequence of this protected area, the Amazonia craton borders have no record of the orogenic processes responsible for the Pangea amalgamation.

Sedimentary covers during supercontinent Pangea existence are widespread in South America platform. In Amazonia craton there was a syneclesis with a important pile of sediments deposited during the Gondwana stabilization. The basin was completely restructured in the beginning of Permian, mostly during Upper Jurassic and Lower Cretaceous. New conditions included development of linear uplift zones, intrusions of diabase dikes and eruption of lavas. Sedimentation was restrict to fluvial and eolian deposits and the Triassic is marked by a major interruption of sedimentation. Pangea break up probably is result of plumes action as recorded by swarm dykes followed by rifting processes and ocean opening.

\section{Conclusions}

Very large supercontinent assemblies developed at several times in the Earth history and the Amazonian craton major tectonic elements may be correlated to these accretionary and collisional processes. Based on geologic, structural and paleomagnetic evidence paleocontinent reconstructions of the Amazonian craton have been proposed from Archean to earlier times as following:

\section{ASSEMBLY OF PANGEA}

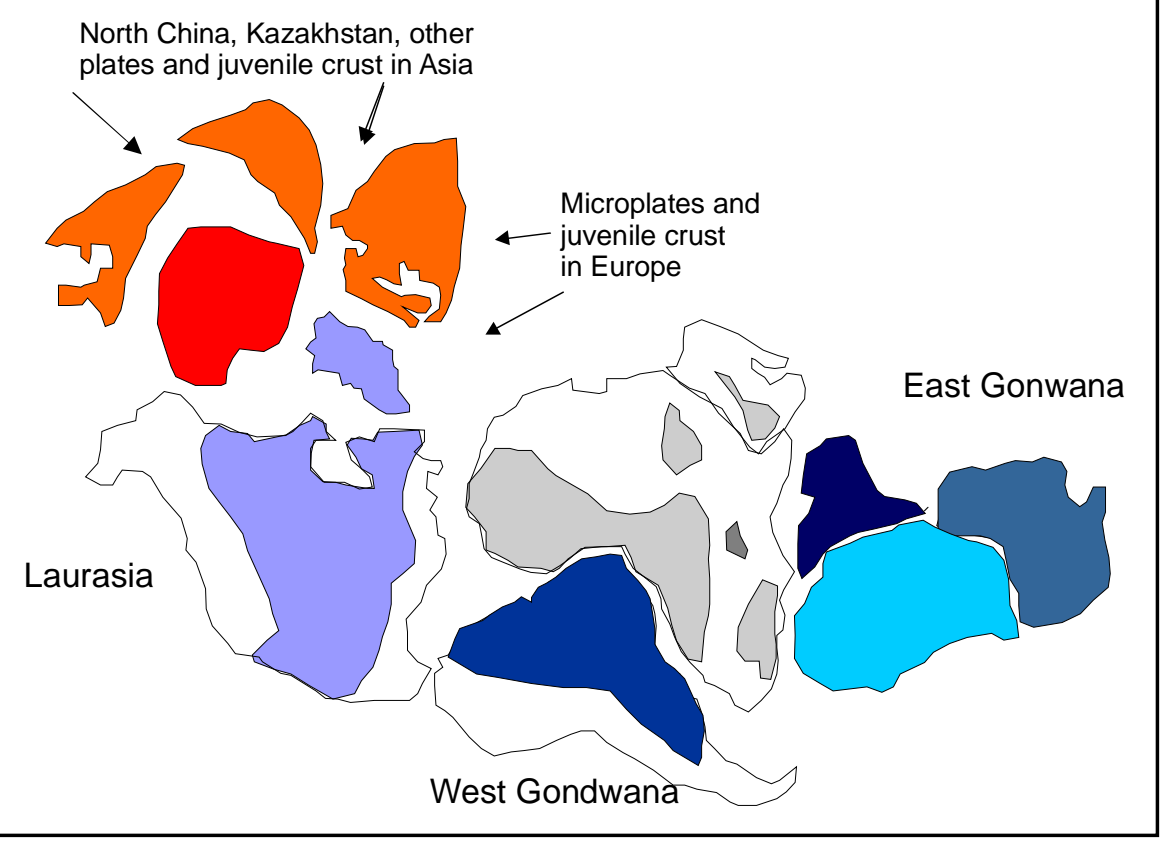

Figure 14. Reconstruction of Pangea (Modified from [32]). 
1) The oldest was Ur continent, with five Achaean cratonic areas (Kaapvaal, Western Dhawar, Bhandara, Singhhum and Pilbara cratons) where 3.0 - 2.8 Ga shallow-water supracrustals assemblages are observed. Coeval sediments of Agua Clara formation intercalated with 2.97 - 2.90 Ga volcanic rocks may suggest the participation of the Achaean rocks of the Carajás region in the Ur landmass.

2) Supercontinental $2.45 \mathrm{Ga}$. Kenorland amalgamation is indicated by paleomagnetic data including Laurentia (Superior and Wyoming cratons), Baltica (Karelia craton), Australia (Yilgarn craton), and Kalahari and Kaapvaal cratons as recorded by glaciogenic and paleoweathering layers. The lack of such suites suggests that Amazonian craton was not part of the Kenorland supercontinent.

3) From 1.83 Ga to 1.25 Ga two supercontinents including Amazonian craton were proposed: Columbia and Hudsonland. They take into account paleomagnetic and tectonic data indicating that NW portion of the Amazonian craton (Maroni/Itacaiunas province) had close connection with West Africa and Kalahari cratons at that time. Paleomagnetic data also indicate Amazonia (Nova Brasilandia) and Laurentia (Llano uplift) connection at $1.2 \mathrm{Ga}$.

4) Rodinia supercontinent reconstructions (AUSWUS, SWEAT and AUSMEX) show Amazonia joined to Laurentia-Baltica as result of $1.1 \mathrm{Ga}$ to $1.0 \mathrm{Ga}$ fusion based on the Sunsas-Aguapei belts and Greenville and Sveconorwegian belts, respectively. The large Late Mesoproterozoic landmass included also Siberia, East Antartica, West Nile, Kalahari, Congo/São Francisco and Greenland.

5) The 750 - 520 Ma Gondwana assembly includes most of the continental fragments rifted apart during the breakup of Rodinia at the beginning of the Neoproterozoic. Successive collision and plate indentation processes during the global orogenic events are described as Brasiliano-Pan African, East Africa and Kuunga belts. The configuration of the South America platform was defined during the Gondwana amalgamation when the Amazonian craton was bordered by the Neoproterozoic belts to the east (Araguaia belt), south (Paraguay belt) and southwest (Tucavaca belt). The Paraguay belt is result of the Rio Apa block and Amazonia craton collision [48] [70]. The Paraguay belt is the results of the Paranapanema block and Amazonia craton collision and the Araguaia belt is result of the Brasilia belt (also Neoproterozoic but previouslly formed) and Amazonian craton collision.

6) The supercontinent Pangea is comprised of Gondwana and Laurentia (or Panotia; [32] Brito Neves, 2002) at about 180 - 300 Ma ago. The Amazonian craton margins were not involved in the collisional processes during Pangea amalgamation because it was imbedded in Neoproterozoic materials. As a consequence, Amazonia craton have no record of the orogenic processes responsible for the Pangea amalgamation.

\section{Acknowledgements}

This paper was improved by discussion with Prof. Randy Van Schmus, Prof. Wilson Teixeira and Prof. Jorge S. Bettencourt. This work was sponsored by CNPq Grant 55.4440/2005-9. This paper is a contribution to IGCP 510: A-type granite and related rocks through time.

\section{References}

[1] Bettencourt, J.S., Tosdal, R.M., Leite JR., W.B. and Payolla, B.L. (1999) Mesoproterozoic Rapakivi Granites of the Rondônia Tin Province, Southwestern Border of the Amazonian Craton, Brazil-I. Reconnaissance U-Pb Geochronology and Regional Implications. Precambrian Research, 95, 41-67. http://dx.doi.org/10.1016/S0301-9268(98)00126-0

[2] Tassinari, C.G., Bettencourt, J.S., Geraldes, M.C., Macambira, M.J.B. and Lafon, J.M. (2000) The Amazon Craton. In: Cordani, U., Milani, E.J., Thomaz Filho, A. and Campos, D.A., Eds., Tectonic Evolution of South America, 31st International Geological Congress, Rio de Janeiro, 41-95.)

[3] Santos, J.O.S., Hartmann, L.A., Gaudette, H.E., Groves, D.I., McNaughton, N.J. and Fletcher, I.R. (2000) A New Understanding of the Provinces of the Amazon Craton Based on Integration of Field Mapping and U-Pb and Sm-Nd Geochronology. Gondwana Research, 3, 453-488. http://dx.doi.org/10.1016/S1342-937X(05)70755-3

[4] Klein, E.L. and Vasquez, M.L. (2000) Projeto Especial Província Mineral do Tapajós. Geologia e recursos minerais da folha SB.21-Z-A—Vila Riozinho, Estado do Pará, escala 1:250,000. Nota Explicativa. CPRM—Serviço Geológico do Brasil (CD-ROM).

[5] Reis, N.J., Faria, M.S.G., Fraga, L.M.B. and Haddad, R.C. (2000) Orosirian Calc-Alkaline Volcanism and the Orocaima Event in the Northern Amazonian Craton, Eastern Roraima State, Brazil. Revista Brasileira de Geociências, 30, 380-383. 
[6] Geraldes, M.C., Van Schmus, W.R., Condie, K.C., Bell, S., Teixeira, W. and Babinski, M. (2001) Proterozoic Geologic Evolution of the SW Part of the Amazonian Craton in Mato Grosso State, Brazil. Precambrian Research, 111, 91-128. http://dx.doi.org/10.1016/S0301-9268(01)00158-9

[7] Avelar, V.G. (2002) Geocronologia Pb-Pb em zircão e Sm-Nd em rocha total da porção centro-norte do Estado do Amapá, Brasil: Implicações para a evolução geodinâmica do setor oriental do Escudo das Guianas. PhD Thesis, Universidade Federal do Pará.

[8] Lamarão, C.N., Dall’Agnol, R., Lafon, J.-M. and Lima, E.F. (2002) Geology, Geochemistry and Pb-Pb Zircon Geochronology of the Paleoproterozoic Magmatism of Vila Riozinho, Tapajós Gold Province, Amazonian Craton, Brazil. Precambrian Research, 119, 189-223. http://dx.doi.org/10.1016/S0301-9268(02)00123-7

[9] Vasquez, M.L., Ricci, P.S.F. and Klein, E.L. (2002) Granitóides pós-colisionais da porçãoleste da Província Tapajós. Contribuições à Geologia da Amazônia, Sociedade Brasileira de Geologia, Belém, Vol. 3, 67-83.

[10] Cordani, U.G. and Teixeira, W. (2007) Proterozoic Accretionary Belts in the Amazonian Craton. In: Hatcher Jr., R.D., Carlson, M.P. and McBride, J.H., Eds., 4-D Framework of Continental Crust. Memoir 220, Geological Society of America, Boulder, CO, 297-320.

[11] Delor, C.,Lahondère, D., Egal, E., Lafon, J.M., Cocherie, A., Guerrot, C., Rossi, P., Trufert, C., Theveniaut, H., Phillips, D. and Avelar, V.G. (2003) Transamazonian Crustal Growth and Reworking as Revealed by the 1:500,000-Scale Geological Map of French Guiana (2nd Edition). Géologie de la France, 2-3-4, 5-57.

[12] Geraldes, M.C., Figueiredo, B.R., Tassinari, C.C.G. and Ebert, H.D. (1997) Middle Proterozoic Vein-Hosted Gold Deposits in the Pontes e Lacerda Region, Southwestern Amazonian Craton, Brazil. International Geology Review, 39, 438-448. http://dx.doi.org/10.1080/00206819709465282

[13] Tohver, E., Teixeira, W., van der Plujm, B., Geraldes, M.C. and Bettencourt, J.S. (2004) Restored Transect across the Exhumed Grenville Orogen of Laurentia and Amazonia, with Implications for Crustal Architecture. Geology, 34, 669672. http://dx.doi.org/10.1130/G22534.1

[14] Rosa-Costa, L.T., Lafon, J.M. and Delor, C. (No Prelo) Zircon Geochronology and Sm-Nd Isotopic Study: Further Constraints for the Archean and Paleoproterozoic Geodynamic Evolution of the Southeastern Guiana Shield, North of Brazil. Gondwana Research.

[15] Fraga, L.M. (2002) A associação anortosito-mangerito-granito rapakivi (AMG) do Cinturão Guiana Central, Roraima, e suas encaixantes Paleoproterozóicas: Evolução estrutural, geocronologia e petrologia. PhD Thesis, Universidade Federal do Pará, Belém, 351 p.

[16] Hoffman, P.F. (1991) Did the Breakout of Laurentia Turn Gondwanaland Inside Out? Science, 252, 1409-1412. http://dx.doi.org/10.1126/science.252.5011.1409

[17] Dalziel, I.W.D. (1992) On the Organization of American Plates in the Neoproterzoic and the Breakout of Laurentia. GSA Today, 2, 1-2.

[18] Dalziel, I.W.D. (1997) Neoproterozoic-Paleozoic Geography and Tectonics: Review, Hypothesis, Environmental Speculation. Geological Society of America Bulletin, 109, 16-42. http://dx.doi.org/10.1130/0016-7606(1997)109<0016:ONPGAT>2.3.CO;2

[19] Moores, E.M. (1991) Southern US-East Antarctic (SWEAT) Connection: A Hypothesis. Geology, 19, 425-428. http://dx.doi.org/10.1130/0091-7613(1991)019<0425:SUSEAS>2.3.CO;2

[20] Unrug, R. (1996) The Assembly of Gondwanaland. Episodes, 19, 11-20.

[21] Sadowski, G.R. and Bettencourt, J.S. (1996) Mesoproterozoic Tectonic Correlations between Eastern Laurentia and the Western Border of the Amazon Craton. Precambrian Research, 76, 213-227. http://dx.doi.org/10.1016/0301-9268(95)00026-7

[22] Bettencourt, J.S., Onstot, T.C. and Teixeira, W. (1996) Tectonic Interpretation of 40Ar/39Ar Ages on Country Rocks from the Central Sector of the Rio Negro-Juruena Province, Southwest Amazonian Craton. International Geology Review, 38, 42-56. http://dx.doi.org/10.1080/00206819709465323

[23] D’Agrella-Filho, M.S., Pacca, I.G., Elming, S.Å., Teixeira, W., Bettencourt, J.S. and Geraldes, M.C. (2001) Preliminary Paleomagnetic Results from Metabasic and Sedimentary Rocks from the Amazonian Craton: Tectonic Implications for the Rodinia Supercontinent. In: Geology of the SW Amazonian Craton: State of the Art, 2001, Instituto de Geociencias-USP, São Paulo, 155-158.

[24] Tohver, E., Van der Pluijm, B.A., Van der Voo, R., Rizzoto, G. and Scandolara, J.E. (2005) Paleogeography of the Amazon Craton at $1.2 \mathrm{Ga}$ : Early Grenvillian Collision with the Llano Segment of Laurentia. Earth and Planetary Science Letters, 199, 185-200. http://dx.doi.org/10.1016/S0012-821X(02)00561-7

[25] Pesonen, L.J., Elming, S.A., Mertanen, S., Pisarevsky, S., D’Agrella Filho, M.S., Meert, J.G., Schmidt, P.W., Abrahamsen, N. and Bylund, G. (2003) Paleomagnetic Configuration of Continents during the Proterozoic. Tectonophysics, 375, 289-324. 
[26] Teixeira, W., Geraldes, M.C., D’Agrella-Filho, M.S., Santos, J.O.S. and Barros, M.A.S.A. (2011) Mesoproterozoic Juvenile Mafic-Ultramafic Magmatism in the SW Amazonian Craton (Rio Negro-Juruena Province): SHRIMP U-Pb Geochronology and Nd-Sr Constraints of the Figueira Branca Suite. Journal of South American Earth Sciences, 32, 309-323. http://dx.doi.org/10.1016/j.jsames.2011.04.011

[27] Van der Voo, R. and Torsvik, T.H. (2001) Evidence for Late Paleozoic and Mesozoic Non-Dipole Fields Provides an Explanation for the Pangea Reconstruction Problems. Earth and Planetary Science Letters, 187, 71-81. http://dx.doi.org/10.1016/S0012-821X(01)00285-0

[28] Hoffman, P.F. (1989) Speculation on Laurentia’s First Gigayear (2,0 to 1,0 Ga). Geology, 17, 135-138. http://dx.doi.org/10.1130/0091-7613(1989)017<0135:SOLSFG>2.3.CO;2

[29] Evans, D.A.D. (2003) True Polar Wander and Supercontinents. Tectonophysics, 362, 303-320. A Palaeomagnetic and 40Ar/39Ar Study of Late Precambrian Sills in the SW part of the Amazonian Craton: Amazonia in the Rodinia Reconstruction.

[30] Condie, K. (1989) Plate Tectonics and Crustal Evolution. Pergamon Press, Oxford, 476 p.

[31] Rogers, J.W. (1996) A History of Continents in the Past Three Billions Years. The Journal of Geology, 104, 91-107. http://dx.doi.org/10.1086/629803

[32] Rogers, J.J.W. and Santosh, M. (2002) Configuration of Columbia, a Mesoproterozoic Supercontinent. Gondwana Research, 5, 5-22. http://dx.doi.org/10.1016/S1342-937X(05)70883-2

[33] Brito Neves, B.B. (2002) Main Stages of the Development of the Sedimentary Basins of South America and Their Relationship with the Tectonic of Supercontinents. Gondwana Research, 5, 175-196. http://dx.doi.org/10.1016/S1342-937X(05)70901-1

[34] Aspler, L.B. and Chiarenzelli, J.R. (1998) Two Neoarchean Supercontinents? Evidence from the Paleoproterozoic. Sedimentary Geology, 120, 75-104. http://dx.doi.org/10.1016/S0037-0738(98)00028-1

[35] Ledru, P., Johan. V., Milési, J.P. and Tegyey, M. (1994) Markers of the Last Stages of the Paleoproterozoic Collision: Evidence for a 2 Ga Continent Involving Circum-South Atlantic Provinces. Precambrian Research, 69, 169-191. http://dx.doi.org/10.1016/0301-9268(94)90085-X

[36] Tassinari, C.C.G. and Macambira, M.J.B. (1999) Geochronological Provinces of the Amazonian Craton. Episodes, 22, 174-182.

[37] Van Schmus, W.R., Geraldes, M.C., Fetter, A.H., Ruiz, A., Matos, J., Tassinari, C.C.G. and Teixeira, W. (1999) Jauru Terrane: A Late Paleoproterozoic Orogen in SW Amazon Craton, Mato Grosso State, Brazil. Journal of Conference Abstracts, 4, 129-130.

[38] Geraldes, M.C., Teixeira, W. and Van Schmus, W.R. (2000) Isotopic and Chemical Evidence for Three Accretioary Magmatic Arcs (1.79-1.42 Ga) in SW Amazon Craton, Mato Grosso Sate, Brazil. Brazilian Journal of Geology, 30, 99-101.

[39] Zhao, G., Sun, M., Wilde, S.A. and Li, S. (2004) A Paleo-Mesoproterozoic Supercontinent: Assembly, Growth and Breakup. Earth-Science Review, 67, 91-123. http://dx.doi.org/10.1016/j.earscirev.2004.02.003

[40] Åhäll, K.-I., Connelly, J.N. and Brewer, T.S. (2000) Episodic Rapakivi Magmatism Due to Distal Orogenesis: Correlation of 1.69-1.50 Ga Orogenic and Inboard, “Anorogenic” Events in the Baltic Shield. Geology, 28, 823-826. http://dx.doi.org/10.1130/0091-7613(2000)28<823:ERMDTD>2.0.CO;2

[41] Geraldes, M.C., Teixeira, W. and Heilbron, M. (2004) Lithospheric versus Asthenospheric Source of the SW Amazonian Craton A-Types Granites: The Role of the Paleo and Mesoproterozoic Accretionary Belts for Their Coeval Continental Suítes. Episodes, 27, 185-189.

[42] Dall’Agnol, R., Ramo, O.T., Magalhães, M.S. and Macambira, M.J.B. (1999) Petrology of the Anorogenic, Oxidised Jamon and Musa Granites, Amazonian Craton: Implications for the Genesis of Proterozoic A-Type Granites. Lithos, 46, 431-462.

[43] Dall’Agnol, R., Teixeira, N.P., Rämö, O.T., Moura, C.A.V., Macambira, M.J.B. and Oliveira, D.C. (2005) Petrogenesis of the Paleoproterozoic Rapakivi A-Type Granites of the Archean Carajás Metallogenic Province, Brazil. Lithos, 80, 101-129. http://dx.doi.org/10.1016/j.lithos.2004.03.058

[44] D’Agrella-Filho, M.S., Tohver, E., Santos, J.O.S., Elming, S.Å., Trindade, R.I.F. and Geraldes, M.C. (2008) Direct Dating of Paleomagnetic Results from Precambrian Sediments in the Amazon Craton: Evidence for Grenvillian Emplacement of Exotic Crust in SE Appalachians of North America. Earth and Planetary Science Letters, 267, 188-199. http://dx.doi.org/10.1016/j.epsl.2007.11.030

[45] Saes, G.S. (1999) Evolução Tectônica e Paleogeográfica do AulacógenoAguapeí (1.2-1.0 Ga) e dos Terrenos do seu Embasamento na Porção Sul do Cráton Amazônico. Unpublished Doctoraldissertation, Universidade de São Paulo, São Paulo, 135 p.

[46] Rizzotto, G.J. (1999) Petrologia e Ambiente Tectônico do Grupo Nova Brasilândia-RO. Unpublished Master’s Disser- 
tation, Universidade Federal do Rio Grando do Sul, Porto Alegre, 136 p.

[47] Geraldes, M.C., Figueiredo, B.R., Tassinari, C.C.G. and Ebert, H.D. (1997) Middle Proterozoic Vein-Hosted Gold Deposits in the Pontes e Lacerda Region, Southwestern Amazonian Craton, Brazil. International Geology Review, 39, 438-448. http://dx.doi.org/10.1080/00206819709465282

[48] Litherland, M., Annels, R.N., Darbyshire, D.P.F., Fletcher, C.J.N., Hawkins, M.P., Klink, B.A., Mitchell, W.I., O’Connor, E.A., Pitfield, P.E.J., Power, G. and Webb, B.C. (1989) The Proterozoic of Eastern Bolivia and Its Relationship to the Andean Mobile Belt. Precambrian Research, 43, 157-174. http://dx.doi.org/10.1016/0301-9268(89)90054-5

[49] Matos, R., Teixeira, W., Geraldes, M.C. and Bettencourt, J.S. (2009) Geochemistry and Nd-Sr Isotopic Signatures of the Pensamiento Granitoid Complex, Rondonian-San Ignacio Province, East Precambrian Shield of Bolívia: Petrogenetic Constraints for a Mesoproterozoic Magmatic Arc Setting. Geologia USP Série Científica, 9, 89-117.

[50] Meert, J.G. and Torsvik, T.H. (2003) The Making and Unmaking of a Supercontinent: Rodinia Revisited. Tectonophysics, 375, 261-288. http://dx.doi.org/10.1016/S0040-1951(03)00342-1

[51] Piper, J.D.A. (1975) Proterozoic Supercontinent: Time Duration and the Grenville Problem. Nature, 256, 519-520. http://dx.doi.org/10.1038/256519d0

[52] Zhao, G., Sun, M., Wilde, S.A., Li, S. and Zhang, J. (2006) Some Key Issues in Reconstructions of Proterozoic Supercontinents. Journal of Asian Earth Sciences, 6, 123-143.

[53] Gower, C.F. and Tucker, R.D. (1994) Distribution of Pre-1400 Ma Crust in the Grenville Province: Implications for Rifting in Laurentia-Baltica during Geon 14. Geology, 22, 827-830. http://dx.doi.org/10.1130/0091-7613(1994)022<0827:DOPMCI>2.3.CO;2

[54] Teixeira, W., Geraldes, M.C., Matos, R., Ruiz, A.S., Saes, G. and Vargas-Mattos, G. (2011) A Review of the Tectonic Evolution of the Sunsás Belt, SW Amazonian Craton. Journal of South American Earth Sciences, 29, 47-60. http://dx.doi.org/10.1016/j.jsames.2009.09.007

[55] Rivers, T. (1997) Lithotectonic Elements of the Grenville Province: Review and Tectonic Implications. Precambrian Research, 86, 117-154. http://dx.doi.org/10.1016/S0301-9268(97)00038-7

[56] Larsen, S.Å. (2000) The Sveconorwegian Tectonic Cycle Reviewed. IGC 2000, Rio de Janeiro, CD-Room.

[57] Jefferson, C.W. (1978) Correlation of Middle and Upper Proterozoic Strata between Northwestern Canada and Central Australia. Geologic Society of America Abstract Program 7, A429.

[58] Dalziel, I.W.D. (1991) Pacific Margin of Laurentia and East Antartica/Australia as a Conjugate Rift Pair: Evidence and Implications for an Eocambrian Supercontinent. Geology, 19, 598-601. http://dx.doi.org/10.1130/0091-7613(1991)019<0598:PMOLAE>2.3.CO;2

[59] Van der Voo, R. and Torsvik, T.H. (2001) Evidence for Late Paleozoic and Mesozoic Non-Dipole Fields Provides an Explanation for the Pangea Reconstruction Problems. Earth and Palnetary Science Letters, 187, 71-81. http://dx.doi.org/10.1016/S0012-821X(01)00285-0

[60] Scandolara, J.E. and Amorim, J.L. (1999) A Faixa Móvel Guaporé, sua definição e inserção no contexto geotectônico do SWdo Craton Amazônico. In: SBG, Simp. Geol. Amaz., 6, Manaus, 1999. Anais..., Manaus, 278-281.

[61] Condie, K. (2004) Supercontinents and Superplume Events: Distinguishing Signals in the Geologic Record. Physics and Earth and Planetary Interiors, 146, 319-332. http://dx.doi.org/10.1016/j.pepi.2003.04.002

[62] Brito Neves, B.B. and Cordani, U.G. (1991) Tectonic Evolution of South America during the Late Proterozoic. Precambrian Research, 53, 23-40. http://dx.doi.org/10.1016/0301-9268(91)90004-T

[63] Weil, A.B., Van der Voo, R., Mac Niocaill, C. and Meert, J.G. (1998) The Proterozoic Supercontinent Rodinia: Paleomagnetically Derived Reconstructions for 1100 to 800 Ma. Earth and Planetary Science Letters, 154, 13-24. http://dx.doi.org/10.1016/S0012-821X(97)00127-1

[64] Brito Neves, B.B., Campos Neto, M.C. and Fuck, R. (1999) From Rodinia to Western Gondwana: An Approach to the Brasiliano-Pan-African Cycle and Orogenic Collage. Episodes, 22, 155-166.

[65] Almeida, F.F.M., Brito Neves, B.B. and Carneiro, C.D.R. (2000) The Origins and Evolution of the South American Platform. Earth Science Review, 50, 77-111. http://dx.doi.org/10.1016/S0012-8252(99)00072-0

[66] Alkmin, F.F., Marshak, S. and Fonseca, M.A. (2001) Assembling West Gondwana in the Neoproterozoic: Clues from the São Francisco Craton Region, Brazil. Geology, 29, 319. http://dx.doi.org/10.1130/0091-7613(2001)029<0319:AWGITN>2.0.CO;2

[67] Meert, J.G. (2003) A Synopsis of Events Related to the Assembly of Eastern Gondwana. Tectonophysics, 362, 1-40. http://dx.doi.org/10.1016/S0040-1951(02)00629-7

[68] Pimentel, M.M. and Fuck, R.A. (1992) Neroproterozoic Crustal Accretion in Central Brazil. Geology, $29,375$. http://dx.doi.org/10.1130/0091-7613(1992)020<0375:NCAICB >2.3.CO;2 
[69] Babinski, M., Chemale Jr., F., Hartmann, L.A., Van Scmuss, W.R. and Silva, L.C. (1996) Juvenile Accretion at 750-700 Ma in Southern Brazil. Geology, 24, 439-442.

http://dx.doi.org/10.1130/0091-7613(1996)024<0439:JAAMIS>2.3.CO;2

[70] Trompette, R. (1994) Geology of Western Gondwana (2000-500): Pan-African-Brasiliano Aggregation of South America and Africa. Balkema, Rotterdam, 350 p. 